\title{
A new species of Anchistrotos (Copepoda: Taeniacanthidae) from hilsa shad, Tenualosa ilisha (Actinopterygii: Clupeidae), off Iraq
}

\author{
B. A. Venmathi Maran ${ }^{1}$, Seong Yong Moon ${ }^{2}$ and Thamir Katea Adday ${ }^{3}$
}

\author{
${ }^{1}$ Marine Ecosystem Research Division, Korea Institute of Ocean Science \& Technology, Ansan, Seoul, Korea; \\ ${ }^{2}$ Fisheries and Ocean Information Division, National Fisheries Research and Development Institute, Busan, Korea; \\ ${ }^{3}$ Department of Fisheries and Marine Resources, College of Agriculture, University of Basrah, Basrah, Iraq
}

\begin{abstract}
A new species of parasitic copepod Anchistrotos tangi sp. n. (Cyclopoida: Taeniacanthidae) is described based on adult female specimens collected from the gills of hilsa shad, Tenualosa ilisha (Hamilton, 1822) (Actinopterygii: Clupeidae) captured off Iraq. The new species differs from its congeners by having the following combination of characters in the adult female: 1) the rostral area sclerotised;2) the presence of row of spinules on the proximal and distal margins of the anal somite; 3) the maxilliped claw with 2 long whip-like setae just crossing the distal edge of claw with serrated terminal margin; and 4) the leg 5 ornamented with patched spinules distally. This is the ninth nominal species of Anchistrotos Brian, 1906.
\end{abstract}

Keywords: taxonomy, fish, parasite, gills, Anchistrotos, maxilliped, whip-like setae

The genus Anchistrotos Brian, 1906 (Copepoda: Cyclopoida) was established by Wilson (1911) to accommodate the type species Anchistrotos gobii (Brian, 1906) in the family Taeniacanthidae Wilson, 1911 based on the presence of maxillipedes made up of a large basal joint and a curved terminal claw, sometimes bearing long setae. Dojiri and Cressey (1987) recognised the validity of the genus Anchistrotos during the revision of the family Taeniacanthidae. The genus Anchistrotos was differentiated from its close congener Taeniacanthus Sumpf, 1981 based on the characteristic features of maxilliped claw with two long whip-like setae extending to or beyond distal limit of claw and the segmentation in leg 1 (Dojiri and Cressey 1987, Boxshall and Halsey 2004). But, Kabata (1992) questioned its validity and proposed to synonymies the new genus with Taeniacanthus. The difference between the two nominal genera Taeniacanthus and Anchistrotos is very indistinct and blurred (Kabata 2003). However, Tang (2006) confirmed that his phylogenetic finding supports Dojiri and Cressey's (1987) premise that Anchistrotos is a valid genus and, accordingly, this taxon cannot be synonymised with Taeniacanthus as proposed by Kabata (1992).

According to the revision of Dojiri and Cressey (1987), Anchistrotos has 6 setae on the maxillule, only 2 blades distally on the mandible (without accessory seta), and 6 setae on the distal segment of leg 1 endopod. In this study, by following the above-mentioned features, a new species of Anchistrotos is described based on the material collected from the hilsa shad, Tenualosa ilisha (Hamilton, 1822) (Actinopterygii: Clupeidae), off Iraq waters in continuation to our recent work (Venmathi Maran et al. 2014).

\section{MATERIALS AND METHODS}

Copepod specimens were carefully removed from the gills of the host fish Tenualosa ilisha using fine forceps and observed under a dissecting microscope. The collected copepods were preserved in $70 \%$ ethanol. Preserved copepods were cleared in a drop of $85 \%$ lactic acid or lactophenol prior to examination using an Olympus BX51 differential phase contrast microscope. Selected specimens were measured intact using an ocular micrometre and/or dissected and examined according to the wooden slide procedure (Humes and Gooding 1964). Measurements given are the range followed by the mean in parentheses. Drawings were made with the aid of a drawing tube. Morphological terminology follows Dojiri and Cressey (1987) and Huys and Boxshall (1991); fish names conform to FishBase (Froese and Pauly 2014). Type specimens are deposited at the National Institute of Biological Resources (NIBR), Incheon, Korea.

\section{RESULTS}

Family Taeniacanthidae Wilson, 1911

Genus Anchistrotos Brian, 1906

Anchistrotos tangi sp. $\mathrm{n}$.

Figs. 1-22

Female (based on one specimen). Body (Fig. 1) $1.36-1.53 \mathrm{~mm}(1.45 \pm 0.78 \mathrm{~mm}, \mathrm{n}=4)$ long (excluding caudal seta) and $0.49-0.54 \mathrm{~mm}$ wide $(0.52 \pm 0.02 \mathrm{~mm}$, 


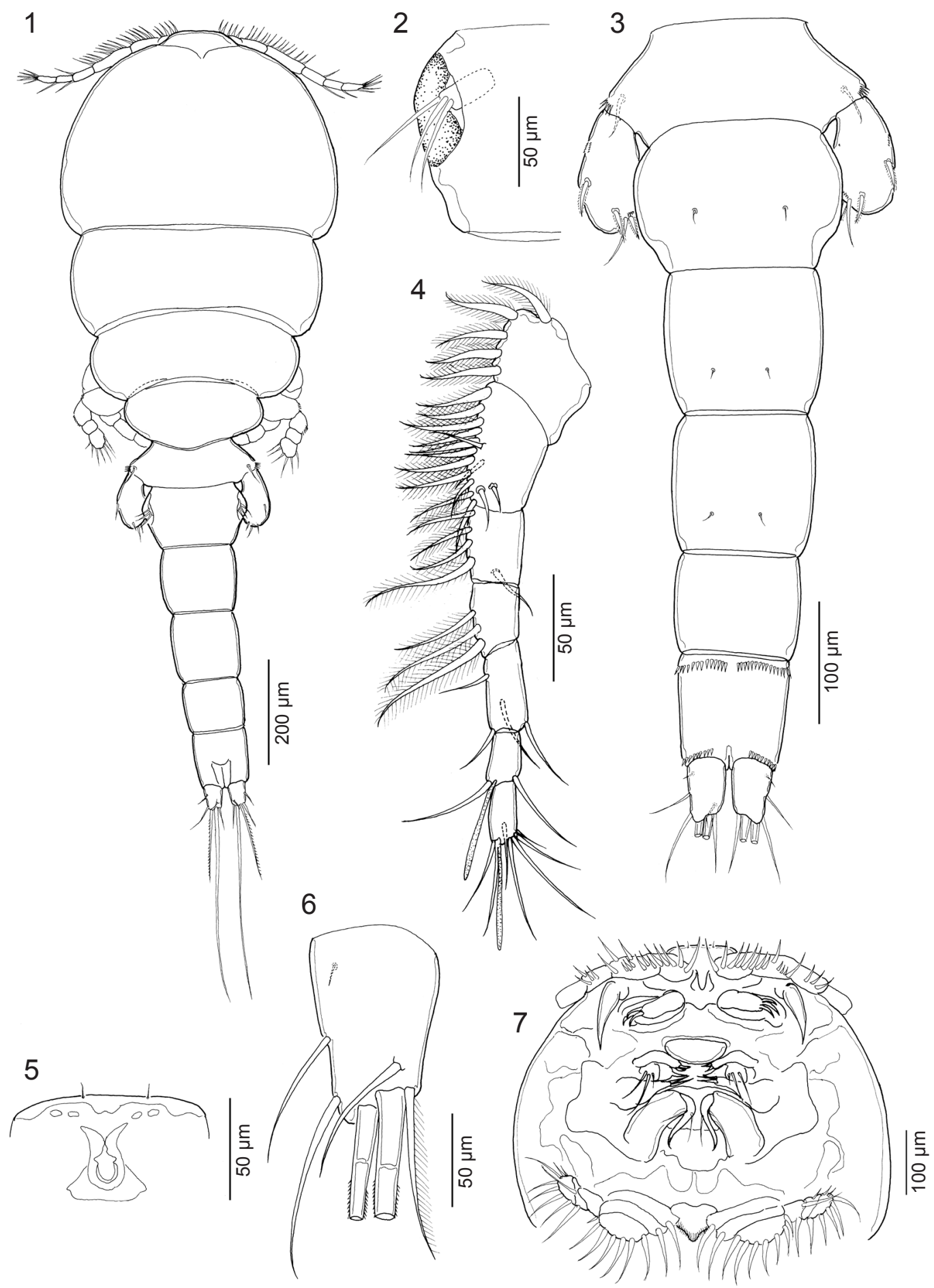

Figs. 1-7. Anchistrotos tangi sp. n. from Tenualosa ilisha, female. Fig. 1. Habitus, dorsal. Fig. 2. Genital somite with leg 6 at the genital opening, dorsal. Fig. 3. Urosome, dorsal. Fig. 4. Antennule, ventral. Fig. 5. Rostral area, ventral. Fig. 6. Caudal ramus, dorsal. Fig. 7. Cephalothorax, ventral.

$\mathrm{n}=4$ ). Prosome composed of broad cephalothorax (first pedigerous somite fused with cephalosome) (Fig. 7) and progressively narrower second to fourth pedigerous somite. Urosome (Fig. 3) comprised of fifth pedigerous somite, genital somite and 4 free abdominal somites. Genital somite (Fig. 2) 1.35 times wider $(191 \mu \mathrm{m})$ than long $(141 \mu \mathrm{m})$. Proportional length (\%) of first to fourth abdominal somites $29.4: 28.4: 20.2: 22.0=100$; first to third abdominal somites naked; distal abdominal somite with transverse rows of stout spinules anteriorly and curved row of stout spinules near insertion of each caudal ramus. Rostral area (Fig. 5) horseshoe-shaped, with scler- 

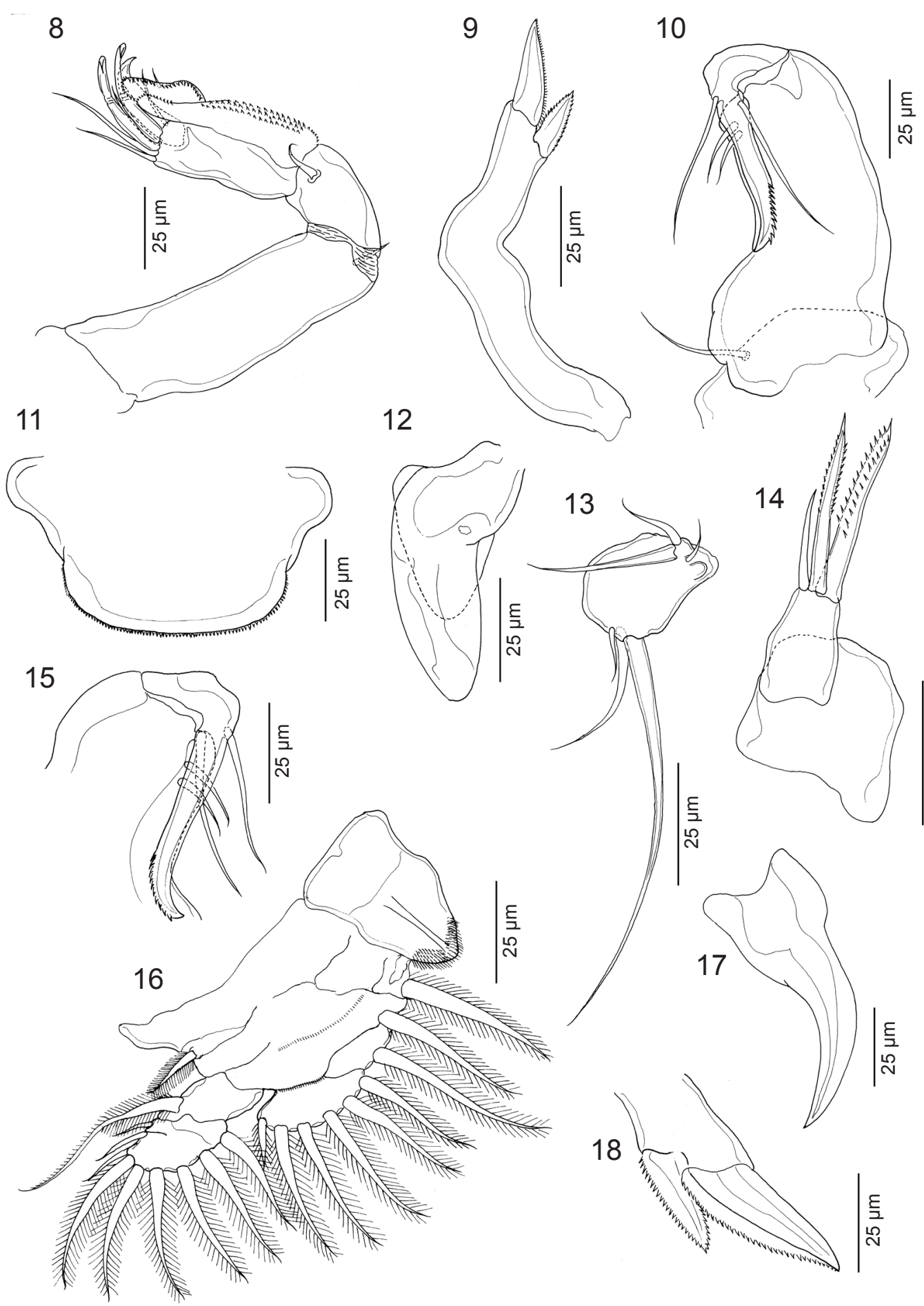

14
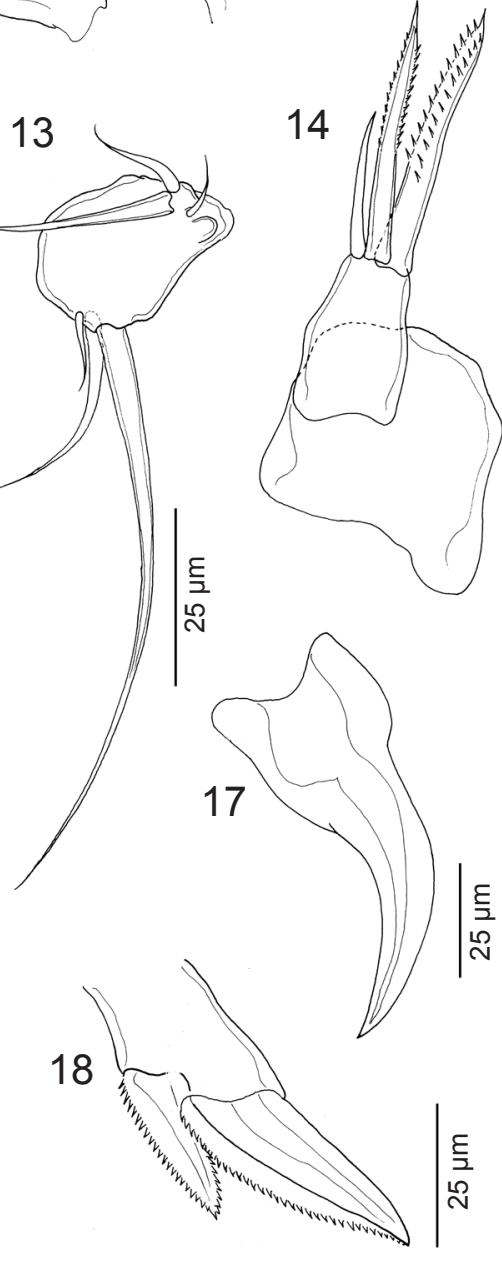

Figs. 8-18. Anchistrotos tangi sp. n. from Tenualosa ilisha, female. Fig. 8. Antenna, dorsal. Fig. 9. Mandible, ventral. Fig. 10. Maxilliped, ventral. Fig. 11. Labrum, ventral. Fig. 12. Paragnath, ventral. Fig. 13. Maxillule, ventral. Fig. 14. Maxilla, ventral. Fig. 15. Distal portion of maxilliped, ventral. Fig. 16. Leg 1, ventral. Fig. 17. Postantennal process, dorsal. Fig. 18. Tip of mandible, ventral.

otised plate. Antennule (Fig. 4) 6-segmented (articulation between ancestral segments a XIV-XVII and XVIII-XX not expressed); armature formula: 5, 15, 8, 4, 2+ 1 aesthetasc and $7+1$ aesthetasc. Caudal ramus (Fig. 6) 1.46 times longer $(57 \mu \mathrm{m})$ than wide $(39 \mu \mathrm{m})$, bearing 7 setae (seta I smallest located anteroventrally); setae II and III with row of minute spinules at base; setae IV and V ornamented with medial row of bristles and lateral row of spinules; seta VI $(57 \mu \mathrm{m})$ about 1.32 times as long as seta VII $(43 \mu \mathrm{m})$; seta V longest $(481 \mu \mathrm{m})$, at least 2.42 times as long as seta IV $(198 \mu \mathrm{m})$. 


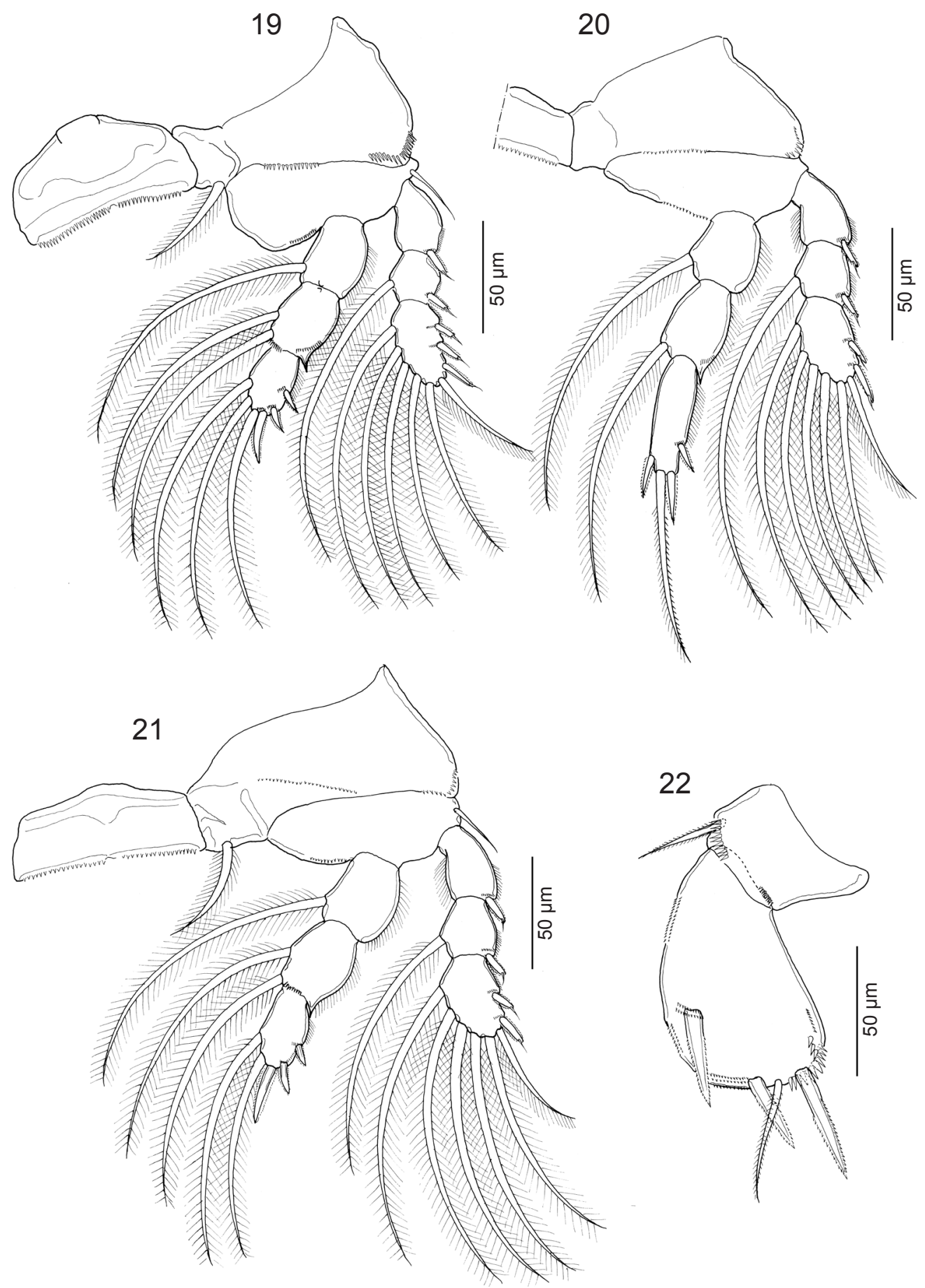

Figs. 19-22. Anchistrotos tangi sp. n. from Tenualosa ilisha, female. Fig. 19. Leg 2, ventral. Fig. 20. Leg 4, ventral. Fig. 21. Leg 3, ventral. Fig. 22. Leg 5, ventral.

Antenna (Fig. 8) composed of coxobasis and 2 endopodal segments; coxobasis with distal seta; proximal endopodal segment with inner seta; second endopodal segment bears 2 unequal pectinate process, 3 claw-like spines and 4 unequal setae; large pectinate process with seta and several rows of spinules; short pecinate process with minute blunt seta and row of spinules. Postantennal process (Fig. 17) relatively elongate, curved distally. La- brum (Fig. 11) with row of tiny spinules along posterior margin. Mandible (Fig. 9) armed with 2 apical blades; both blades spinulate along inner margin (Fig. 18). Paragnath (Fig. 12) robust, blunt with proximal patch of setules. Maxillule (Fig. 13) lobate, small knob-like process anteriorly, bearing 2 long (outer $98 \mu \mathrm{m}$, inner $21 \mu \mathrm{m}$ ) and 4 short naked setae. Maxilla (Fig. 14) 2-segmented; syncoxa unarmed; basis armed with 2 long spinulate spines 
Venmathi Maran et al.: New species of parasitic copepod from Iraq

Table 1. Hosts and localities of collections of all nine species of the genus Anchistrotos (Copepoda: Taeniacanthidae).

\begin{tabular}{|c|c|c|c|c|}
\hline Copepod & Host & Host order: family & Locality & Reference \\
\hline $\begin{array}{l}\text { Anchistrotos caligiformis } \\
\text { (Gurney, 1927) }\end{array}$ & Sea weed & - & Port Said, Egypt & Gurney (1927) \\
\hline $\begin{array}{l}\text { Anchistrotos gobii } \\
\text { (Brian, 1906) }\end{array}$ & $\begin{array}{l}\text { Gobius cobitis Pallas } \\
\text { G. paganellus Linnaeus }\end{array}$ & $\begin{array}{l}\text { Perciformes: Gobiidae } \\
\text { Perciformes: Gobiidae }\end{array}$ & $\begin{array}{l}\text { Lebanon } \\
\text { Naples, Italy }\end{array}$ & Brian (1906) \\
\hline $\begin{array}{l}\text { Anchistrotos kojimensis } \\
\text { Do et Ho, } 1983\end{array}$ & $\begin{array}{l}\text { Acanthogobius flavimanus } \\
\text { (Temminck et Schlegel) }\end{array}$ & Perciformes: Gobiidae & Kojima Bay, Japan & Do and Ho (1983) \\
\hline Anchistrotos laqueus & Serranus scriba (Linnaeus) & Perciformes: Serranidae & Livarno, Italy & Leigh-Sharpe (1935) \\
\hline Leigh-Sharpe, 1935 & $\begin{array}{l}\text { S. cabrilla (Linnaeus) } \\
\text { Ciliata mustela (Linnaeus) }\end{array}$ & $\begin{array}{l}\text { Perciformes: Serranidae } \\
\text { Gadiformes: Lotidae }\end{array}$ & $\begin{array}{l}\text { Haifa Bay, Israel, } \\
\text { Tunisia } \\
\text { Baltic Sea, England }\end{array}$ & Kabata (1979) \\
\hline $\begin{array}{l}\text { Anchistrotos lucipetus } \\
\text { Holmes, } 1985\end{array}$ & Underwater light trap & - & Lough Ine, Ireland & Holmes (1985) \\
\hline $\begin{array}{l}\text { Anchistrotos onosi } \\
\text { (Scott, 1902) }\end{array}$ & $\begin{array}{l}\text { C. mustela } \\
\text { Enchelyopus cimbrius (Linnaeus) }\end{array}$ & $\begin{array}{l}\text { Gadiformes: Lotidae } \\
\text { Gadiformes: Lotidae }\end{array}$ & Plymouth, UK & $\begin{array}{l}\text { Scott (1902), } \\
\text { Stock (1953), } \\
\text { Yamaguti (1963), } \\
\text { Kabata (1979), }\end{array}$ \\
\hline Anchistrotos tangi sp. $\mathrm{n}$. & Tenualosa ilisha (Hamilton) & Clupeiformes: Clupeidae & Iraq & Present study \\
\hline $\begin{array}{l}\text { Anchistrotos wilsoni } \\
\text { (Scott, 1929) }\end{array}$ & Leucoraja fullonica (Linnaeus) & Rajiformes: Rajidae & Irish Sea, Ireland & $\begin{array}{l}\text { Scott (1929), } \\
\text { Kabata (1979) }\end{array}$ \\
\hline $\begin{array}{l}\text { Anchistrotos zeugopteri } \\
\text { Scott, } 1902\end{array}$ & Zeugopterus punctatus (Bloch) & Pleuronectiformes: Scophthalmidae & $\begin{array}{l}\text { Clyde Estuary } \\
\text { Roscoff, France }\end{array}$ & $\begin{array}{l}\text { Scott (1902), } \\
\text { Leigh-Sharpe (1939), } \\
\text { Yamaguti (1963), } \\
\text { Kabata (1979), }\end{array}$ \\
\hline
\end{tabular}

and naked seta. Maxilliped (Figs. 10) 3-segmented; first segment with usual seta; second segment (corpus) with 2 proximal naked setae and distomedial protrusion; terminal segment elongate, curved distally, bearing 2 equal naked, long setae (Fig. 15), with minute spinules medially to apically and well-developed inner basal protrusion ornamented with hyaline membrane.

Legs 1-4 biramous (Figs. 16, 19-21); leg 1 (Fig. 16) with 2-segmented rami; remaining legs with 3-segmented rami. Armature on rami of legs $1-4$ as follows (Roman numerals - spines; Arabic numerals - setae):

\begin{tabular}{lcccc}
\hline & Coxa & Basis & Exopod & Endopod \\
\hline Leg 1 & $0-1$ & $1-1$ & $1-0 ;$ I-1; 7 & $0-1 ; 6$ \\
Leg 2 & $0-1$ & $1-0$ & I- 0 ; I-1; III, I, 5 & $0-1 ; 0-2 ;$ II, I, 3 \\
Leg 3 & $0-1$ & $1-0$ & I-0; I-1; II, I, 5 & $0-1 ; 0-2 ;$ II, I, 2 \\
Leg 4 & $0-0$ & $1-0$ & I-0; I-1; II, I, 5 & $0-1 ; 0-1 ;$ IV \\
\hline
\end{tabular}

Leg 1 (Fig. 16) coxa, basis and rami flattened. Intercoxal sclerite subtriangular, ornamented with fine spinules on anterodistal surface. Coxa with patch of setules on outer border; coxa and basis ornamented with rows of minute spinules. Outer margin of second endopodal segment with patch of setules. Leg 2 (Fig. 19) intercoxal sclerite triangular, ornamented with rows of spinules along posterior margin. Coxa with large spinules along distolateral side on anterior surface. Leg 2 exopodal spine spinulate along outer margin, each with accessory terminal flagellum; outer margin of exopod segment ornamented with row of spinules. Leg 2 endopodal segment with row of spinules along lateral margin; second endopodal segment also protruded slightly at distolaterally and with row of setules along outer border; spine on terminal segment spinulate along outer margin.
Intercoxal sclerite of legs 3 (Fig. 21) and 4 (Fig. 20) wider than long, spinulate along posterior margin. Coxa and basis of legs 3 and 4 similar to those of leg 2, except without inner row of spinules on basis. Structure of spines and ornamentation on rami of legs 3 and 4 as in leg 2, except terminal segment of leg 4 endopod with additional outer row of setules. Second endopodal segments of legs 3 and 4 with distolateral protrusion and spinules along outer margin.

Leg 5 (Fig. 22) well developed, 2-segmented. Protopodal segment unornamented, armed with dorsolateral pinnate seta. Free exopodal segment 2.7 times longer $(186 \mu \mathrm{m})$ than wide $(69 \mu \mathrm{m})$, ornamented with patch of spinules on distomedial surface and row of spinules at base of each spine and armed with 3 spinulate spines and seta. Leg 6 (Fig. 2) vestigial, represented by opercular plate armed with 3 naked setae at genital opening.

Male. Unknown.

Type host: Tenualosa ilisha (Hamilton) (Actinopterygii: Clupeidae) (21 July 2011).

Site of infection: Gills.

Type 1 ocality: Off Iraq waters $\left(29^{\circ} 46^{\prime} \mathrm{N} ; 48^{\circ} 51^{\prime} \mathrm{E}\right)$.

Material examined: Holotype female (NIBRIV0000287187) and 1 paratype female (NIBRIV0000287188) deposited in the collections of NIBR, Incheon, Korea.

Etymology: The species named in honour of Dr. Danny Tang (USA) for his contribution to the knowledge of parasitic copepods, especially the family Taeniacanthidae.

Remarks. The new species closely resembles $A$. onosi (Scott, 1902) and A. kojimensis Do et Ho, 1983 but differs in the following features: 1) the rostral area sclerotised ( $v S$ not sclerotised in both species); 2) the presence of row of spinules on the proximal and distal margins of the anal 
somite ( $v s$ absence of spinules in $A$. onosi; present, but in different format in A. kojimensis); 3 ) the leg 5 ornamented with patched spinules distally ( $v s$ absence of spinules in both species). The new species differs from all other congeners in the length of 2 setae in the maxilliped. All species have been found with 2 long whip-like setae of $0.5-1$ time longer than maxilliped $i e$ : beyond the distal edge of the maxilliped, however, in the new species those 2 long setae are just crossing the distal edge of claw, not as long as like its other congeners. The new species shares this feature with $A$. kojimensis, but differs in the setal numbers of the termimal exopodal segment of leg 2. It is provided with III, I, 5 setae, but II, I, 5 in A. kojimensis.

According to Do and Ho (1983), there are 17 nominal species of the genus Anchistrotos. However, Dojiri and Cressey (1987) transferred 11 species to the genus Taeniacanthus and retained six species under Anchistrotos. Further, Tang (2006) transferred Taeniacanthus wilsoni Scott, 1929 to Anchistrotos based on the redescription of Kabata (1992) and phylogenetic analysis. Likewise, Huys et al. (2012) have transferred recently Taeniacanthus zeugopteri (Scott, 1902) back to Anchistrotos based on a phylogenetic analysis using complete $18 \mathrm{~s}$ ssrDNA sequences. Hence, Anchistrotos currently comprised nine species including the new species. These are $A$. caligiformis (Gurney, 1927), A. gobii Brian, 1906, A. kojimensis, A. laqueus Leigh-Sharpe, 1935, A. lucipetus Holmes, 1985, A. onosi, A. wilsoni (Scott, 1929), A. zeugopteri Scott, 1902 and $A$. tangi sp. n. Most species parasitise teleost fishes (Table 1).

Species of Anchistrotos have so far been reported from British waters, the Mediterranean Sea and the western North Pacific (Dojiri and Cressey 1987, Suh et al. 1992, Boxshall and Halsey 2004, Tang 2006) and for the first time off Iraq waters. Out of nine species, seven are reported from fishes, but two, A. caligiformis and A. lucipetus, were collected from seaweed at Port Said, Egypt (Gurney 1927) and with an underwater light trap at Lough Ine, Ireland (Holmes 1985), respectively (Table 1). Since all other species are recorded as parasites of fishes, these two are likewise expected to be parasites of fish (Dojiri and Cressey 1987, Tang 2006).

Acknowledgements. Senior author acknowledges KIOST project (PO01110, PE99202, PG48020). TKA is grateful to Prof. N.R. Khamees and authorities of University of Basrah, Iraq for study leave and facilities for research.

\section{REFERENCES}

Boxshall G.A., Halsey S.H. 2004: An Introduction to Copepod Diversity. The Ray Society, London, 966 pp.

Brian A. 1906: Copepodi parassiti dei Pesci d'Italia. Genova, Stab. Tipo-Litografico R. Instituto Sordomuti: 1-190.

Do T.T., Ho J.-S. 1983: Anchistrotos kojimensis sp. nov. (Copepoda: Taeniacanthidae) parasitic on Acanthogobius flavimanus (Pisces: Teleostei) in Kojima Bay, Japan. Fish Pathol. 18: 1-5.

Dojiri M., Cressey R.F. 1987: Revision of the Taeniacanthidae (Copepoda: Poecilostomatoida) parasitic on fishes and sea urchins. Smithsonian Cont. Zool. 447: 1-250.

Froese R., Pauly D. (Eds.) 2014: FishBase. World Wide Web electronic publication. http://www.fishbase.org, 3/2014.

Gurney R. 1927: Report on the Crustacea Copepoda (littoral and semi-parasitic). Trans. Zool. Soc. London 22: 451-577.

Holmes J.M.C. 1985: Anchistrotos lucipetus sp. nov. (Copepoda, Taeniacanthidae), a parasitic copepod from Lough Ine, south west Ireland. Crustaceana 48: 18-25.

Humes A.G., Gooding R.U. 1964: A method for studying the external anatomy of copepods. Crustaceana 6: 238-240.

Huys R., Boxshall G.A. 1991: Copepod Evolution. The Ray Society, London, $468 \mathrm{pp}$.

Huys R., Fatih F., Ohtsuka S., Hughes J.L. 2012: Evolution of the bomolochiform superfamily complex (Copepoda: Cyclopoida): new insights from ssrDNA and morphology, and origin of umazuracolids from polychaete-infesting ancestors rejected. Int. J. Parasitol. 42: 71-92.

Kabata Z. 1979: Parasitic Copepoda of British Fishes. The Ray Society, London, $468 \mathrm{pp}$.

Kabata Z. 1992: Copepods Parasitic on Fishes. In: D.M. Kermack, R.S.K. Barnes and J.H. Crothers (Eds.), Synopses of the British Fauna (New Series), Vol. 47. Universal Book Services/ Dr W. Backhuys, Oegstgeest, The Netherlands, 264 pp.

Kabata Z. 2003: Copepods Parasitic on Fishes. In: J.H. Crothers and P.J. Hayward (Eds.), Synopses of the British Fauna (New
Series), Vol. 47 (revised). The Linnean Society \& The Estuarine \& Coastal Sciences Association, London, 274 pp.

Leigh-Shar Pe W.H. 1935: Anchistrotos laqueus n. sp. a parasitic copepod of Serranus cabrilla. Parasitology 27: 266-269.

Leigh-Sharpe W.H. 1939: Anchistrotos zeugopteri (T. Scott), a parasitic copepod of Zeugopterus punctatus. Parasitology 31: $166-170$.

Sсотт A. 1929: The copepod parasites of Irish sea fishes. Proc. Tran. Liverpool Biol. Soc. 43: 81-119.

Scotт T. 1902: Notes on some parasites of fishes. Rep. Fish. Bd Scotland 20: 288-303.

Sun H.L., Sнiм J.D., Chоі S.D. 1992: Four species of Copepoda (Poecilostomatoida) parasitic on marine fishes of Korea. Bull. Kor. Fish. Soc. 25: 291-300.

Sтоск J.H. 1953: Bomolochus solea Claus, 1864 and B. confusus n. sp.: two hitherto con-founded parasitic copepods, with remarks on some other Bomolochus species. Beaufortia 2: 1-13.

TANG D. 2006: Phylogeny of the copepod family Taeniacanthidae. Proceedings of the 11th International Congress of Parasitology, Glasgow, UK, 6-11 August 2006, Medimond, Bologna, pp. 621-625.

Venmathi Maran B.A., Moon S.Y., Adday T.K., Khamees N.R., Myoung J.-G. 2014: Three new records of copepods (Siphonostomatoida) parasitic on marine fishes of Iraq, including the relegation of two species of Lernanthropinus to Lernanthropinus temminckii (Nordmann, 1864). Acta Parasitol. 59: $139-152$.

WiLson C.B. 1911: North American parasitic copepods belonging to the family Ergasilidae. Proc. U.S. Natl. Mus. 39: 263-400; Plates 41-60.

Yamaguti S. 1963: Parasitic Copepoda and Branchiura of Fishes. Interscience Publishers, New York, 1103 pp.

Accepted 15 March 2014 